4-бөлім

Қолданылмалы

математика

IRSTI 27.35.29
Раздел 4

Прикладная

математика

DOI: https://doi.org/10.26577/JMMCS.2020.v106.i2.08

Section 4

Applied
Mathematics

A.U. Abdibekova*, D.B. Zhakebayev, O. Karuna

Al-Farabi Kazakh National University, Almaty, Kazakhstan

*e-mail: a.aigerim@gmail.com

\title{
MODELLING THE INFLUENCE OF ELECTRON CONCENTRATION ON MHD TURBULENCE BY LES
}

In the present work, a three-dimensional mathematical model of the influence of electron concentration on the dynamics of the E-layer of the ionosphere under nonisothermal conditions is developed. The proposed method shows high computational efficiency and good quality estimates. To approximate the solution of the convective and diffusion terms of the intermediate velocity field, the finite difference method is used in combination with a five-diagonal matrix, which made it possible to achieve fourth-order accuracy in space and third-order accuracy in time. To solve the pressure, the Poisson equation is solved, which ensures the fulfillment of the continuity equation. The Poisson equation is transformed from physical space to spectral space using the Fourier transform. The equation for the temperature and electron concentration is solved using the AdamsBashforth method. Before modeling the influence of the magnetic field on MHD turbulence, to test the adequacy of the numerical algorithm, the Taylor Green test problem was performed for various Reynolds numbers, where it agrees well with the reference spectral method and analytical solutions. As a result of the simulation, the temperature contours and turbulent flow isotherms for various Stuart numbers were obtained. The developed numerical algorithm can be used to model the attenuation of ionospheric turbulence at various Stuart numbers.

Key words: Ionosphere E-layer, concentration of electron, magnetohydrodynamics, Taylor-Green vortex problem, finite difference method.

$$
\begin{gathered}
\text { А.У. Абдибекова*, Д.Б. Жакебаев, О. Каруна } \\
\text { Әл-Фараби атындағы Қазақ Ұлттық Университеті, Алматы қ., Қазақстан } \\
\text { *e-mail: a.aigerim@gmail.com }
\end{gathered}
$$

Ірі қүйындылық әдісін қолдану арқылы электрон концентрацияның МГД турбуленттілігіне әсерін моделдеу

Осы жұмыста электрон концентрациясының ионосфераның Е-қабатының динамикасына әсер етудің үш өлшемді математикалық моделі құрылған. Ұсынылған әдіс жоғары есептеу тиімділігін және сапаны жақсы бағалауды көрсетеді. Аралық жылдамдық өрісінің конвективті және диффузиялық бөліктерін аппроксимациялау үшін ақырлы айырмдылық әдісі бес диагональды матрицамен бірге қолданылады, бұл кеңістік бойынша төртінші ретті дәлдікке және уақыт бойынша үшінші ретті дәлдікке қол жеткізуге мүмкіндік берді. Қысымды шешу үшін үздіксіздік теңдеуінің орындалуын қамтамасыз ететін Пуассон теңдеуі шешіледі. Пуассон теңдеуі Фурье түрлендіру әдісі көмегімен физикалық кеңістіктен спектрлік кеңістікке ауыстырылады. Температура мен электрон концентрациясының теңдеуі Адамс-Башфорт әдісі арқылы шешіледі. Магниттік өрістің МГД турбуленттілігіне әсерін модельдеуден бұрын, сандық алгоритмнің сәйкестігін тексеру үшін, Тейлор Грин сынақтары Рейнольдстың әртүрлі сандары үшін жүргізілді, салыстыру нәтижесінде құрылған сандық әдістің шешімі спектральды әдісімен және аналитикалық шешімдермен жақсы келісімде көрсетті. Модельдеу нәтижесінде турбулентті ағынның әртүрлі Стюарт сандары үшін температура контурлары мен изотермалары алынды. Әзірленген сандық алгоритм Стюарттың әртүрлі сандарындағы ионосфералық турбуленттіліктің үрдісіне әсерін зерттеуге арналды.

Түйін сөздер: Ионосфера Е-қабаты, электронның концентрациясы, магнитогидродинамика, Тейлор-Грин құйындығының есебі, ақырлы айырмдылық әдісі. 


\author{
А.У. Абдибекова*, Д.Б. Жакебаев, О. Каруна \\ Казахский Национальный Университет имени аль-Фараби, г. Алматы, Казахстан \\ *e-mail: a.aigerim@gmail.com \\ Моделирование влияния концентрации электронов на МГД-турбулентность методом \\ крупных вихрей
}

В представленной работе разработана трехмерная математическая модель влияния концентрации электронов на динамику Е-слоя ионосферы в неизотермических условиях. Предложенный метод показывает высокую вычислительную эффективность и хорошее качество оценки. Для аппроксимации решения конвективного и диффузионного членов промежуточного поля скоростей используется метод конечных разностей в сочетании с пятидиагональной матрицей, который позволил достичь точности четвертого порядка в пространстве и третьего порядка во времени. Для решения давления решается уравнение Пуассона, которое обеспечивает выполнение уравнения неразрывности. Уравнение Пуассона преобразуется из физического пространства в спектральное пространство с помощью преобразования Фурье. Уравнение для температуры и концентрации электронов решается с использованием метода Адамса-Бэшфорта. Перед моделированием влияния магнитного поля на МГД турбулентность, для проверки адекватности численного алгоритма была выполнена тестовая задача Тейлора Грина для различных чисел Рейнольдса, где она хорошо согласуется с эталонным спектральным методом и аналитическими решениями. В результате моделирования были получены температурные контуры и изотермы турбулентного потока для различного числа Стюарта. Разработанный численный алгоритм может быть использован для моделирования затухания ионосферной турбулентности при различных числах Стюарта.

Ключевые слова: ионосфера Е-слой, концентрация электронов, магнитная гидродинамика, вихревая задача Тейлора-Грина, метод конечных разностей.

\title{
1 Introduction
}

Extensive research has been undertaken over the past decades to improve our knowledge of the Earth surrounding ionosphere. The ionosphere layer is consisting of neutral and charged particles that interact with each other and are exposed to external influences of solar origin and are limited by gravitational, electric and magnetic fields. To simulate the ionosphere medium means to find a satisfactory description of the behavior of its constituent particles in a selected space interval in time. Modeling is necessary because it is impossible to observe the structure and dynamics of the environment in all places and at any time. We will consider the E layer of the ionosphere, which corresponds to an altitude of approximately $90-120$ $\mathrm{km}$. There is every reason to believe that at these altitudes the gas is weakly ionized, degree of ionization $\mathrm{Ne} / \mathrm{Nn}$ is quite small $\mathrm{Ne} / \mathrm{Nn}<<1$, where $\mathrm{Ne}$ and $\mathrm{Nn}$ are the electron and molecule concentrations, respectively.

\section{Literature review}

It is well - known that instabilities produce turbulence in ionosphere [1,2] and significant amount of researches have been to study instabilities and their application to ionosphere turbulence. The chaotic behavior of ionosphere electron density fluctuations resulting from the interchange instabilities has been investigated [3], and describing the evolution of the Rayleigh-Taylor and $E \times B$ gradient drift instabilities which are relevant to the ionosphere and reduce to equation which correspond exactly to the Lorenz attractor for Rayleigh-Benard instability $[4,5]$. In the developed three-mode system of chaotic behavior the ion inertia plays 
a critical role in that if it is neglected, the three mode system does not exhibit chaos and a stable convection results [3]. In [6] is shown in the inertial regime, for which the threemode theory predicts chaos, and the large-scale turbulence cell do not show chaotic behavior. We present our results for three mode systems, which corresponds to the Rayleigh Benard problem. The concept of convection is quite old, however the first quantitative experiments were performed by Henri Benard [7]. He studied the stability of a thin fluid layer open to air and submitted to a vertical temperature gradient, where he accurately determined properties such as the space periodicity of the hexagonal pattern, its variation, the profile of the interface. Later, Lord Rayleigh [8] proposed his theory of a feedback coupling resting on buoyancy: a fluid particle hotter than its environment encounters ever-colder fluid as it rises, which leads to the instability. He developed a complete linear stability analysis assuming stress-free conditions for the velocity and good heat-conducting plates. From the computational point of view, it was shown in [9], that the dynamic LES method can be a useful tool for modeling weakly ionized magnetohydrodynamic turbulence at low $R e_{m}$ values and large N. In fact, since Joule dissipation leads to an energy sink proportional to the amplitude of the velocity fluctuation at each magnetic field. On the whole, large scales make a significant contribution to the dissipation of kinetic energy. Therefore, since the role of the energy cascade is less dominant compared to hydrodynamic turbulence, small-scale modeling can save significant computational resources.

\section{Materials and methods}

In the framework of this study, to construct a mathematical model of the influence of electron concentration on the dynamics of changes in the heterogeneity of the E-layer of the ionosphere under non-isothermal conditions, we consider an incompressible electrically conductive medium with different electron concentration at the three dimensional area. Some assumptions like no charge separation is observed inside the electrically conductive liquid [10], the Lorentz force decreases to the magnetic part have been made. For a very wide range of problems, assuming that relativistic effects are negligible, the nonlinear MHD equations are directly derived from Maxwell's equations, so the only relevant equations relate to speed and magnetic fields. However, even for these specific problems, the Lorentz force in the Navier Stokes equations can be specified by various expressions depending on the range of parameters characterizing the flow [10]. It is known that turbulent fluctuations become anisotropic in the presence of a sufficiently strong magnetic field, which has important con- sequences for the properties of the turbulence and possibly requires a modification of the numerical models applied to such flows. If $R e_{m} \geq 1$, there is a two-way coupling between the fluctuations of the magnetic field and the velocity [11,12]. As the fluid moves in the applied magnetic field B, induced electric currents result in the Lorentz force affecting the flow and in the modification of the imposed field by perturbations b of comparable or even larger amplitude. This happens, for example, in astro-physical processes, in stars, the interstellar medium, etc., where $R e_{m}<<1$, and in geophysics, the geodynamics, where $R e_{m}=10^{2}$ [13]. 


\subsection{Statement of the problem}

The applied magnetic field $B=-H_{0} \bar{j}$ effect in the Navier-Stokes equations is the inclusion of the Lorentz force to the momentum equations $F_{l}=J \times B$ where $J=\sigma(E+V \times B)-$ is electric current density $E$ - is electric field strength, which we set equal to zero, and $\sigma$ is electric conductivity, $V=u_{1} \bar{i}+u_{2} \bar{j}+u_{3} \bar{k}$ - velocity of fluid, and all of these in combination we obtain $F_{l}=\sigma(V \times B) \times$ - Lorentz force, where $F_{l}=\sigma\left[\left(u_{1} \bar{i}+u_{2} \bar{j}+u_{3} \bar{k}\right) \times\left(-H_{0} \bar{j}\right)\right] \times\left(-H_{0} \bar{j}\right)$ is in detail, after using the properties of the multiplication of unit vectors, we obtain $F_{l}=$ $\sigma\left(u_{1} H_{0} \bar{k}-u_{3} H_{0} \bar{i}\right) \times\left(-H_{0} \bar{j}\right)$, or $F_{l}=\sigma\left(-u_{1} H_{0}^{2} \bar{i}-u_{3} H_{0}^{2} \bar{k}\right)$, and $F_{l}=F_{1}+F_{2}+F_{3}$, where $F_{1}=-\sigma u_{1} H_{0}^{2} \bar{i}, F_{2}=0, F_{3}=\sigma u_{3} H_{0}^{2} \bar{k}[14]$.

To construct a mathematical model of the influence of external disturbances on the generation and evolution of large-scale inhomogeneities in the E-layer of the ionosphere, we consider the transport equation for the magnetic field, which underlies the theory of incompressible MHD:

$$
\left\{\begin{array}{l}
\frac{\partial\left(\bar{u}_{i}\right)}{\partial t}+\frac{\partial\left(\bar{u}_{i} \bar{u}_{j}\right)}{\partial x_{j}}=-\frac{\partial \bar{p}}{\partial x_{i}}-\frac{\partial \tau_{i j}^{u}}{\partial x_{j}}+\frac{1}{R e} \frac{\partial}{\partial x_{j}}\left(\frac{\partial \bar{u}_{i}}{\partial x_{j}}\right)+F_{i}+\frac{R a}{R e^{2} P r} \bar{\theta} \\
\frac{\partial\left(\bar{u}_{i}\right)}{\partial x_{i}}=0 \\
\frac{\partial(\bar{\theta})}{\partial t}+\frac{\partial\left(\bar{u}_{i} \bar{\theta}\right)}{\partial x_{j}}=\frac{1}{\operatorname{RePr}} \frac{\partial}{\partial x_{j}}\left(\frac{\partial \bar{\theta}}{\partial x_{j}}\right)-\frac{\partial}{\partial x_{j}}\left(\tau_{j}^{\theta}\right) \\
\frac{\partial n_{e}}{\partial t}+u_{j} \frac{\partial n_{e}}{\partial x_{j}}=\frac{\partial}{\partial x_{j}}\left(\nu_{T} \frac{\partial n_{e}}{\partial x_{j}}\right) \\
\tau_{i j}^{u}=\left(\overline{u_{i} u_{j}}-\left(\bar{u}_{i} \bar{u}_{j}\right)\right. \\
\tau_{j}^{\theta}=\left(\overline{u_{j} \theta}-\left(\bar{u}_{j} \bar{\theta}\right)\right.
\end{array}\right.
$$

where $\overline{u_{1}}, \overline{u_{2}}, \overline{u_{3}}$ - are velocity components, $x_{1}, x_{2}, x_{3}$ - coordinates, $\bar{F}_{1}=-\bar{n} N_{0} \bar{u}_{1}, \bar{F}_{2}=0$, $\bar{F}_{3}=-\bar{n} N_{0} \bar{u}_{3}$ - non-dimensional Lorentz force [14], $N=\sigma L H_{0}^{2} / \rho V_{0}=n_{e} N_{0}$ is the Stuart number, where $N_{0}=\sigma_{0} H_{0}^{2} L_{3} /\left(\rho_{0} U_{0}\right)=H a^{2} / R e, H a=H_{0} L \sqrt{\sigma / \mu}$ - Hartmann number, $H$ magnetic field strength, $\sigma$ is the conductivity of the medium, which is determined from plasma physics $\sigma=e^{2} n_{e} /\left(m_{e} v_{i}\right)=n_{e} \sigma_{0}$, where $e$-elcetron charge, $m_{e}$ - electron mass, $n_{e}$ electron concentration, $v_{i}$ - effectivr electron collision frequency in the ionosphere. $\bar{p}$ is the full pressure, $t$ is the time, $U_{0}=\sqrt{\alpha D\left(T_{1}-T_{0}\right) L_{3}}$ - characteristic velocity, $\bar{\theta}=\left(T-T_{0}\right) /\left(T_{1}-T_{0}\right)$ - nondimensional temperature, where $T_{0}$ and $T_{1}$ are respectively the minimum and maximum temperatures in the E layer of ionosphere, $R a=\alpha g\left(T_{1}-T_{0}\right) L_{3}^{3} /(\nu D)$ - Rayleigh number, where $\alpha$ is volumetric thermal expansion coefficient, $g$ acceleration due to gravity, $R e=\sqrt{R a / P r}$ is the Reynolds number, and to compare numerical simulation results with the work [14]. $\operatorname{Pr}=\nu / D$ - Prandtl number, $D$ - diffusion coefficient, $L_{1}=L_{2}=L_{3}=L$ is the typical length of the domain, $\nu$ is the kinematic viscosity coefficient, $\rho$ is the density of the flow, $t$ nondimensional time, $\tau_{i j}^{u}, \tau_{j}^{\theta}$ are the subgrid -scale tensors responsible for small -scale structures to be modelled, $\tau_{j}^{\theta}=\alpha_{s g s} \frac{\partial \bar{\theta}}{\partial x_{j}}$, where $\alpha_{s g s}=C_{s}^{2} / P r_{s g s} \Delta^{2}|\bar{S}|=C_{s}^{2} / P r_{s g s} \Delta^{2}\left(2 \bar{S}_{i j} \bar{S}_{i j}\right)^{\frac{1}{2}}$ is 
the thermal eddy diffusivity, where $P r_{\text {sgs }}=0.6$.

A schematic picture of the computational domain is shown in Figure 1, where the top layer - indicated by the blue color, corresponds to a medium with a strong electron concentration and a low temperature environment of the ionosphere. The bottom layer - highlighted in red, corresponds to a weakly electronic concentrated and high temperature environment of the ionosphere.

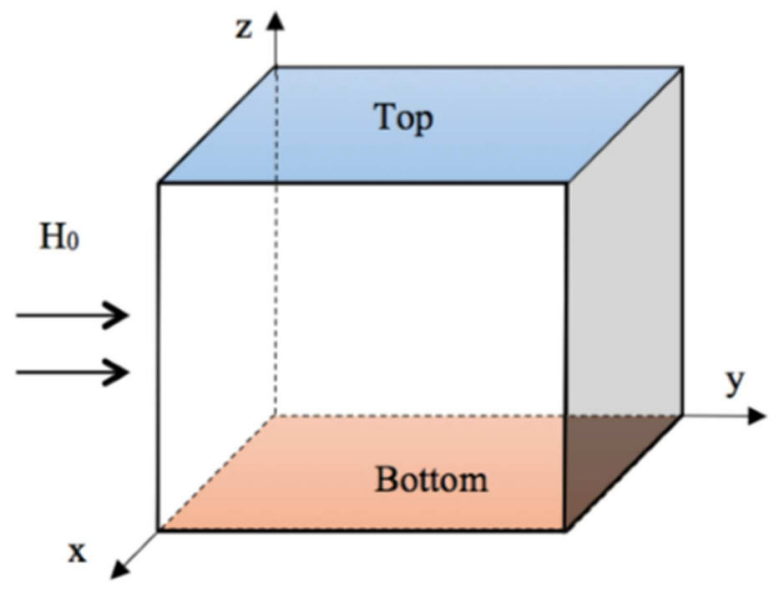

Figure $1-$ Illustration of the problem statement

Initial conditions for temperature, velocity components are set zero in all directions of the domain, and for electron concentration is $n_{e}=1$.

The boundary conditions imposed for temperature, and electron concentration are Dirichlet on the lower and upper boundary, and Neumann on the other directions of the domain. The velocity components are equal to 0 in all directions.

Top:

$u_{1}, u_{2},\left.u_{3}\right|_{\text {top }}=0$

$\left.\theta\right|_{\text {top }}=\theta_{\text {cold }}=0$, where $\theta_{\text {cold }}$ - the lowest temperature of the ionosphere layer is set,

$\left.n_{e}\right|_{t o p}=1$ - concentrated medium.

Bottom:

$u_{1}, u_{2},\left.u_{3}\right|_{\text {bottom }}=0$

$\left.\theta\right|_{\text {bottom }}=\theta_{\text {hot }}=1$, where $\theta_{\text {cold }}$ - the high temperature of the ionosphere layer is set,

$\left.n_{e}\right|_{\text {bottom }}=0$ - weak concentrated medium.

Other walls:

$$
\begin{aligned}
& \frac{\partial \theta}{\partial x_{1}}=0, \frac{\partial \theta}{\partial x_{2}}=0 \\
& \frac{\partial n_{e}}{\partial x_{1}}=0, \frac{\partial n_{e}}{\partial x_{2}}=0
\end{aligned}
$$




\subsection{Numerical method}

To solve the problem of homogeneous incompressible MHD turbulence, a scheme of splitting by physical parameters is used:

$$
\begin{aligned}
& \text { I. } \frac{\left(\bar{u}^{*}\right)^{n+1}-(\bar{u})^{n}}{\Delta t}-\frac{1}{2 R e} \nabla^{2}\left(\bar{u}^{*}\right)^{n+1}=\frac{1}{2 R e} \nabla^{2} \bar{u}^{n}+\frac{3}{2} K^{n}-\frac{1}{2} K^{n-1} ; \\
& \text { II. } \Delta p=\frac{\nabla\left(\bar{u}^{*}\right)^{n+1}}{\tau} ; \\
& \text { III. } \frac{(\bar{u})^{n+1}-\left(\bar{u}^{*}\right)^{n+1}}{\Delta t}=-\nabla p ; \\
& \text { IV. } \frac{\bar{\theta}^{n+1}-\bar{\theta}^{n}}{\Delta t}-\frac{1}{2 P e} \nabla^{2} \bar{\theta}^{n+1}=\frac{1}{2 P e} \nabla^{2} \bar{\theta}^{n}+\left(\frac{3}{2} G^{n}-\frac{1}{2} G^{n-1}\right) \\
& \text { V. } \frac{\bar{n}_{e}^{n+1}-\bar{n}_{e}^{n}}{\Delta t}-\frac{1}{2} \nabla\left(\nu_{T} \nabla \bar{n}_{e}^{n+1}\right)=\frac{1}{2} M^{n}-\frac{1}{2} M^{n-1}+\frac{1}{2} \nabla\left(\nu_{T} \nabla \bar{n}_{e}^{n}\right)
\end{aligned}
$$

where

$$
\begin{aligned}
& K^{n}=-\left(\bar{u}^{n} \nabla\right) \bar{u}^{n}+F^{n}+\left(\operatorname{Ra} / \operatorname{Re} e^{2} \operatorname{Pr}\right) \bar{\theta}^{n}-\left(\nabla \tau^{u}\right)^{n}, \\
& M^{n}=-\left(\bar{u}^{n} \nabla\right) \bar{n}_{e}^{n}, \\
& G^{n}=-\left(\bar{u}^{n} \nabla\right) \bar{\theta}^{n}--\left(\nabla \tau^{\theta}\right)^{n} \text {, where } \operatorname{Pe}=\operatorname{Re} \operatorname{Pr} \text { - Peclet number. }
\end{aligned}
$$

During the first stage, the full magneto hydrodynamic equation system is solved without the pressure consideration. For approximation of the convective and diffusion terms of the intermediate velocity field a finite-difference method in combination with penta-diagonal matrix is used, which allowed to increase the order of accuracy in space. The numerical algorithm for the solution of incompressible MHD turbulence without large eddy simulation is considered at [15]. The intermediate velocity field is solved using the Adams-Bashfort scheme in combination with the five-point sweep method. At the second step, the pressure Poisson equation is solved, which ensures that the continuity equation is satisfied. The Poisson equation is transformed from the physical space into the spectral space by using a Fourier transform. To solve the three-dimensional Poisson equation, the spectral conversion in combination with matrix sweeping algorithm is developed [15]. The resulting pressure field in the third stage is used to recalculate the final velocity field [16]. At the fourth stage, the equation for temperature is solved by using Adams-Bashforth scheme. At the fifth stage, for the solution of concentration electron equation the similiar algorithm as for solution of temperature the Adams Bashforth scheme is used.

\section{Analitical solution of Taylor-Green vortex problem}

We duplicate the classical example proposed in [17] in order to validate the numerical simulation of increasing order of accuracy in time and in space $O\left(d t^{2}, h^{4}\right)$, with efficient acceleration for sequential algorithm. Starting from a simple incompressible three-dimensional initial condition of the form.

$$
\left\{\begin{array}{l}
u_{1}\left(x_{1}, x_{2}, x_{3}, t=0\right)=\cos \left(a x_{1}\right) \sin \left(a x_{2}\right) \sin \left(a x_{3}\right) \\
u_{2}\left(x_{1}, x_{2}, x_{3}, t=0\right)=-\sin \left(a x_{1}\right) \cos \left(a x_{2}\right) \sin \left(a x_{3}\right), \\
u_{3}\left(x_{1}, x_{2}, x_{3}, t=0\right)=0
\end{array}\right.
$$


and assuming periodic conditions in a cubic domain: $0 \leqslant x_{1} \leqslant 2 \pi, 0 \leqslant x_{2} \leqslant 2 \pi, 0 \leqslant x_{3} \leqslant 2 \pi$ with $a=1$, the three-dimensional filtered Navier-Stokes equation

$$
\frac{\partial u_{i}}{\partial t}+u_{j} \frac{\partial u_{i}}{\partial x_{j}}=-\frac{1}{\rho} \frac{\partial p}{\partial x_{i}}+\frac{1}{\operatorname{Re}} \frac{\partial^{2} u_{i}}{\partial x_{i} \partial x_{j}}
$$

can be solved analytically at small times, using the method of perturbation expansion. In (1) all quantities have been properly normalized by the initial maximum velocity magnitude $U_{0}$ in the $x_{1}$ or $x_{2}$ direction, and $L / 2 \pi$, where $L$ is the physical domain size, $u_{i}$-velocity at $i=1,2,3$, corresponding to $x_{1}, x_{2}, x_{3}$ directions, $\mathrm{Re}=L U_{0} / \nu$ is the Reynolds number of flow, $U_{0}$ - the characteristic velocity, $T=a U_{0} t, a=2 \pi / L$. The pressure $p$ has been normalized by $\rho U_{0}^{2}$. Taylor and Green obtained a perturbation expansion of the velocity field, up to $O\left(t^{5}\right)$. The resulting average kinetic energy is:

$$
E_{k}=\frac{U_{0}^{2}}{8} u^{\prime 2}
$$

where

$$
\begin{gathered}
u^{\prime 2}=1-\frac{6 T}{\operatorname{Re}}+\frac{18 T^{2}}{\operatorname{Re}^{2}}-\left(\frac{5}{24}+\frac{36}{\operatorname{Re}^{2}}\right) \frac{T^{3}}{\operatorname{Re}}+\left(\frac{5}{2 \operatorname{Re}^{2}}+\frac{54}{\operatorname{Re}^{4}}\right) T^{4}- \\
-\left(\frac{5}{44.12}+\frac{367}{24 \mathrm{Re}^{2}}+\frac{4.81}{5 \operatorname{Re}^{4}}\right) \frac{T^{5}}{\operatorname{Re}}+\left(\frac{361}{44.32}+\frac{761}{12 \operatorname{Re}^{2}}+\frac{324}{5 \mathrm{Re}^{4}}\right) \frac{T^{6}}{\operatorname{Re}^{2}} .
\end{gathered}
$$

The dissipation rate is written in the following form:

$$
W=\mu \frac{3 U_{0}^{2} a^{2}}{4} W^{\prime}
$$

where

$$
\begin{aligned}
W^{\prime}=\left(\frac{5}{48}+\frac{18 T^{2}}{\operatorname{Re}^{2}}\right) T^{2}-\left(\frac{5}{3}+\frac{36}{\mathrm{Re}^{2}}\right) \frac{T^{3}}{\mathrm{Re}}+1-\frac{6 T}{\operatorname{Re}}+ \\
+\left(\frac{50}{99.64}+\frac{1835}{9.16 \mathrm{Re}^{2}}+\frac{54}{\operatorname{Re}^{4}}\right) T^{4}-\left(\frac{361}{44.32}+\frac{761}{12 \operatorname{Re}^{2}}+\frac{324}{5 \operatorname{Re}^{4}}\right) \frac{T^{5}}{\operatorname{Re}} .
\end{aligned}
$$

Simulation at different Reynolds numbers was compared with the analytical solution of the Taylor-Green vortex problem from the point of view of: the average kinetic energy and the average dissipation rate of the turbulent flow. Figure 2 compares the average turbulent kinetic energy obtained in this paper with the analytical solution of the Taylor-Green vortex problem for different Reynolds numbers. The results obtained by analytical solution of short-time theory of TG, spectral methods at $256^{3}$ grid resolution and hybrid finite difference method at $64^{3}$ grid resolution show a satisfactory agreement till $T=3$ at $R e=100$, and till $T=4$ at $R e=300$, and $R e=600$ for the average turbulent kinetic energy. The error between analytical and numerical solutions for the average kinetic energy was defined as: $\operatorname{Error}\left(E_{k}\right)=\left|E_{k}^{H F D M}-E_{k}^{T G}\right|=10^{-4}$. 


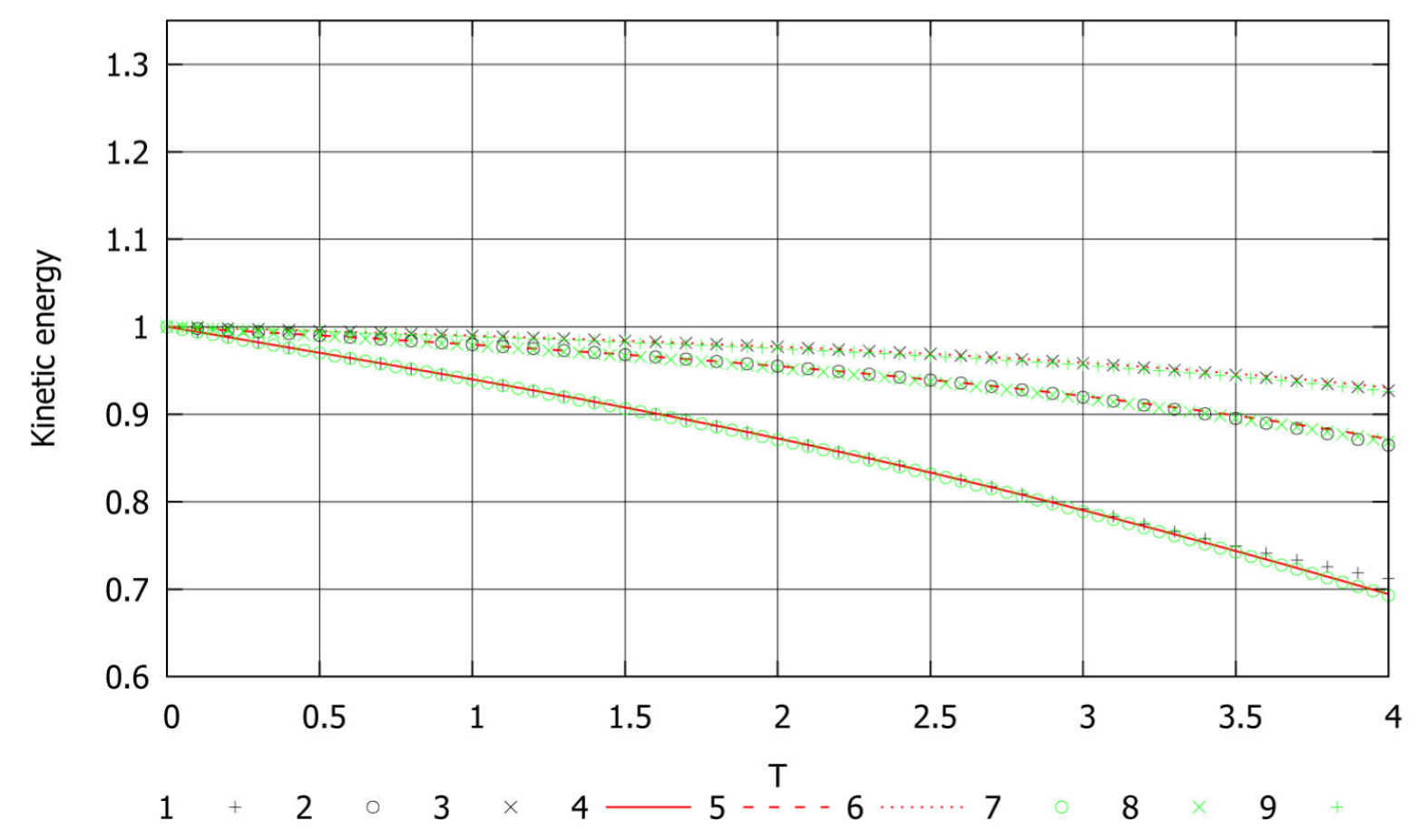

Figure $2-$ Comparative results of modeling the evolution of the average kinetic energy in time, spectral and hybrid methods of modeling the Taylor-Green vortex of: TG short-time theory at: 1) $\operatorname{Re}=100 ; 2) \operatorname{Re}=300 ; 3) \mathrm{Re}=600$; Spectral method, $256^{3}$ at: 4) $\left.\mathrm{Re}=100 ; 5\right) \mathrm{Re}=300$; 6) $\mathrm{Re}=600$; HFD method at: 7) $\mathrm{Re}=100 ; 8) \mathrm{Re}=300$; 9) $\mathrm{Re}=600$.

Fig. 2. Comparative results of modeling the evolution of the average kinetic energy in time, spectral and hybrid methods of modeling the Taylor-Green vortex of: TG shorttime theory at: 1) $\operatorname{Re}=100 ; 2) \operatorname{Re}=300 ; 3) \operatorname{Re}=600$; Spectral method, $256^{3}$ at: 4) $\operatorname{Re}=100$; 5 ) $\mathrm{Re}=300$; 6) $\mathrm{Re}=600$; HFD method, $64^{3}$ at: 7) $\mathrm{Re}=100$; 8) $\mathrm{Re}=300$; 9) $\mathrm{Re}=600$.

Figure 3 compares the results of average rate of dissipation of the turbulence decay with respect to time of the numerical simulation, and the analytical solution of the Taylor-Green vortex problem at different Reynolds number. It can be seen from Figure 3 that the shortterm theoretical results and numerical simulation results are in good agreement till $T=2.5$ for $R e=100$, and $T=2$ for $R e=300 ; R e=600$. It is difficult to compare the analytical solution with numerical simulation, since the analytical solution valid only for short-term time, and the numerical solution can provide good results for long term, so it is worthwhile to compare simulation results of spectral method and HFD method for long term. The rate of dissipation increases sharply due to the formation of small-scale flow structures and reaches a maximum at $T=3$, for short time theory of $T G$ at $R e=100$, and at $T=4$ for other case, and then the rate of dissipation shows a decrease in the tendency for result of analytical solution of TG at $R e=100$ because of the decrease in the total Reynolds number of the stream. In the simulation results, the error between analytical and numerical solutions for the average dissipation rate is: $\operatorname{Error}(\epsilon)=\left|\epsilon^{H F D M}-\epsilon^{T G}\right|=10^{-2}$. 


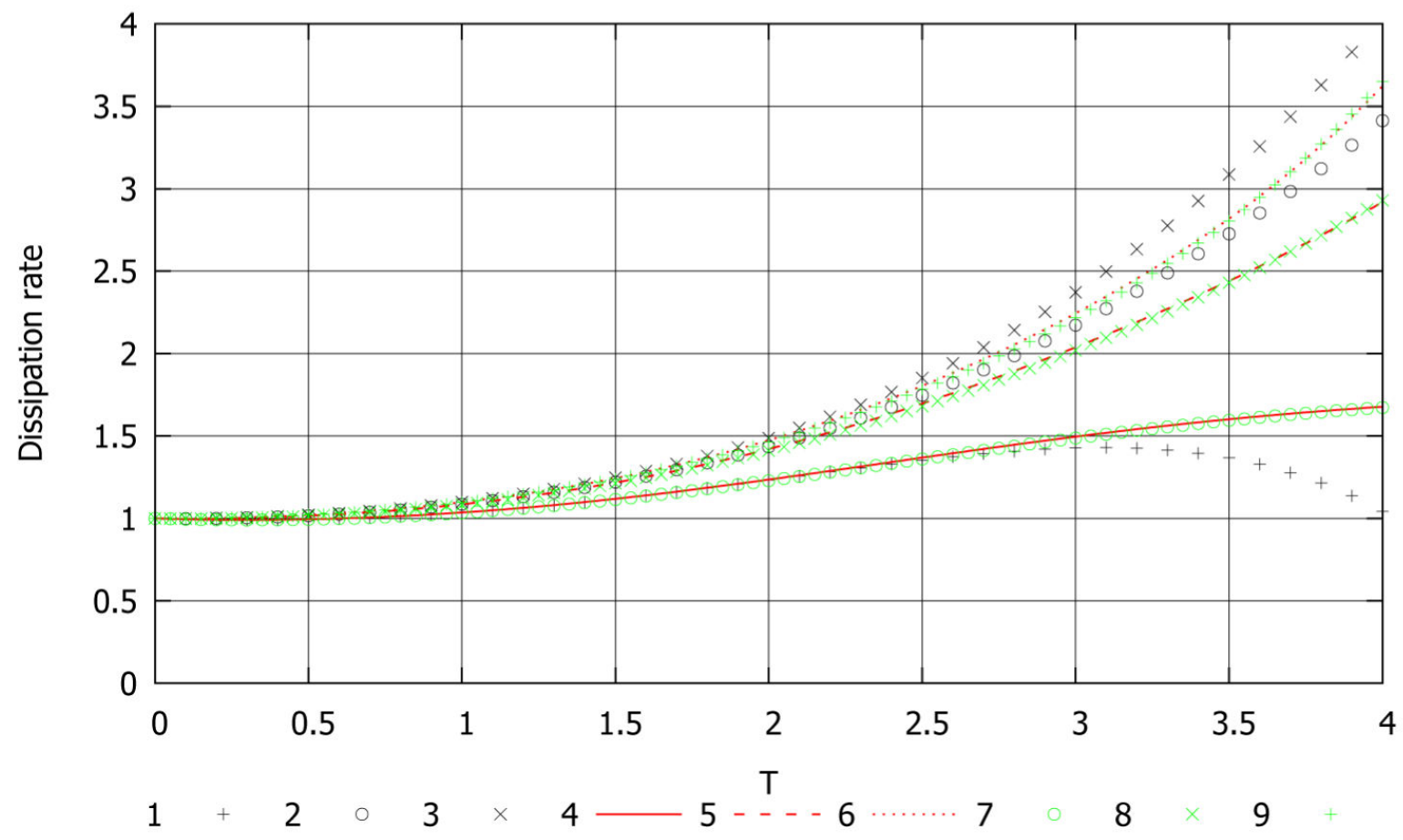

Figure $3-$ Comparative results of modeling the evolution of the average rate of dissipation of the decay of turbulence in time, the spectral and hybrid methods of modeling the Taylor-Green vortexof: TG short-time theory at: 1) $\mathrm{Re}=100 ; 2) \mathrm{Re}=300$; 3) $\mathrm{Re}=600$; Spectral method, $256^{3}$ at: 4$\left.\left.) \operatorname{Re}=100 ; 5\right) \operatorname{Re}=300 ; 6\right) \operatorname{Re}=600$; HFD method at: 7$\left.) \operatorname{Re}=100 ; 8\right) \operatorname{Re}=300$; 9) $\mathrm{Re}=600$.

\section{Results and discussion}

The numerical model allows one to describe the influence of electron concentration on the dynamics of changes in the inhomogeneities of the E-layer of the ionosphere under nonisothermal conditions. The mathematical model of the problem is based on solving non-stationary equations of magnetohydrodynamics with filtration in combination with the continuity equation, equations for temperature, equations of electron concentration, equations for the motion of charged particles, taking into account the continuity equation in a Cartesian coordinate system in dimensionless form. For this problem, the Stuart number has the following values a) $N_{0}=0$; b) $N_{0}=1$, the Rayleigh number is taken $R a=10^{6}$, and Prandtl number is $\operatorname{Pr}=0.7$. For calculations, a grid size is taken $64 \times 64 \times 64$. The domain size are equal to $L_{1}=2 \pi ; L 2=2 \pi ; L 3=2 \pi$, corresponding accord to the $x_{1}, x_{2}$ and $x_{3}$ directions. As a result of modeling at various Stuart numbers Rayleigh Benard convection is obtained. At figure 4-9 it is shown temperature convection at different Stuart number, and at different sections. It is seen, that with the increase interaction number, the development of heat transfer flow is more stable and static than where it is neglected. Heat transfer is largely suppressed by an external magnetic field. Convection flow will completely disappear under the action of the inhibitory force of the magnetic field.

In this study, to construct a mathematical model of the influence of electron concentration on the dynamics of changes in the heterogeneity of the E-layer of the ionosphere under non- 


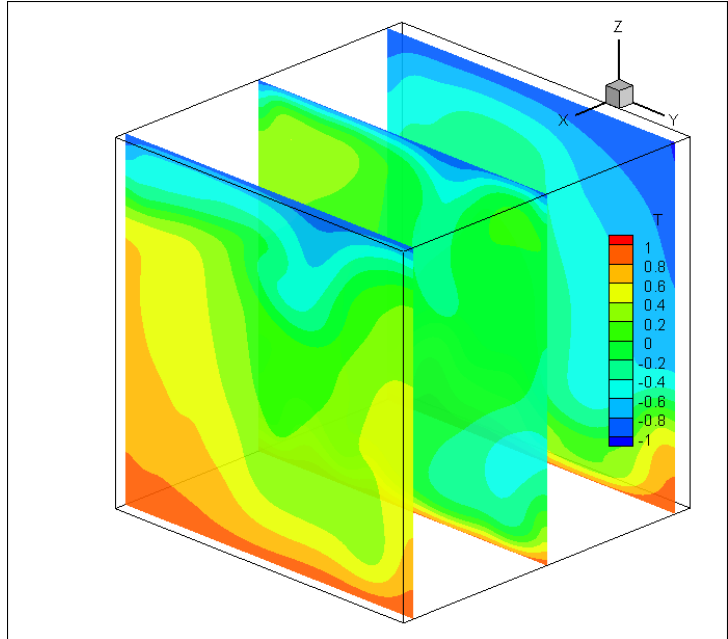

a)

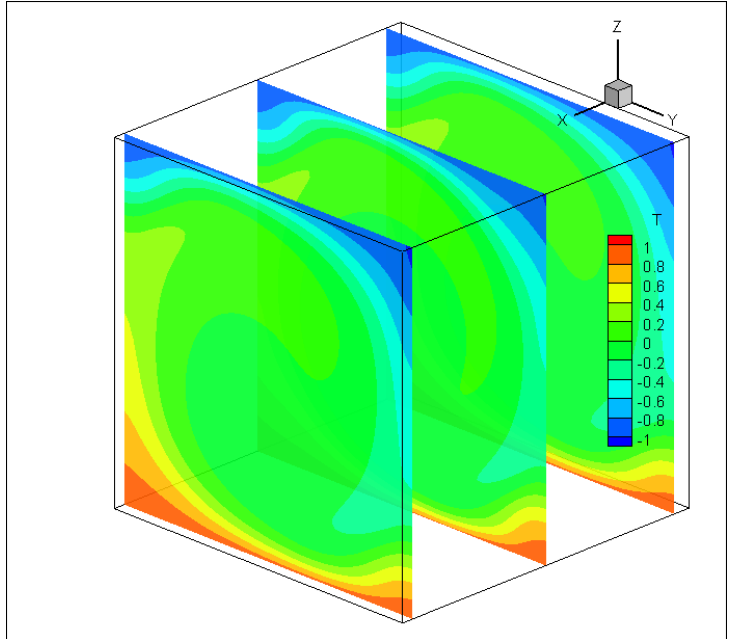

b)

Figure $4-$ Temperature contour of the turbulent flow for different interaction coefficients a) $N_{0}=0$ and $N_{0}=1$ at different sections: $x_{1}=0.05 ; x_{1}=0.5 ; x_{1}=0.95$.

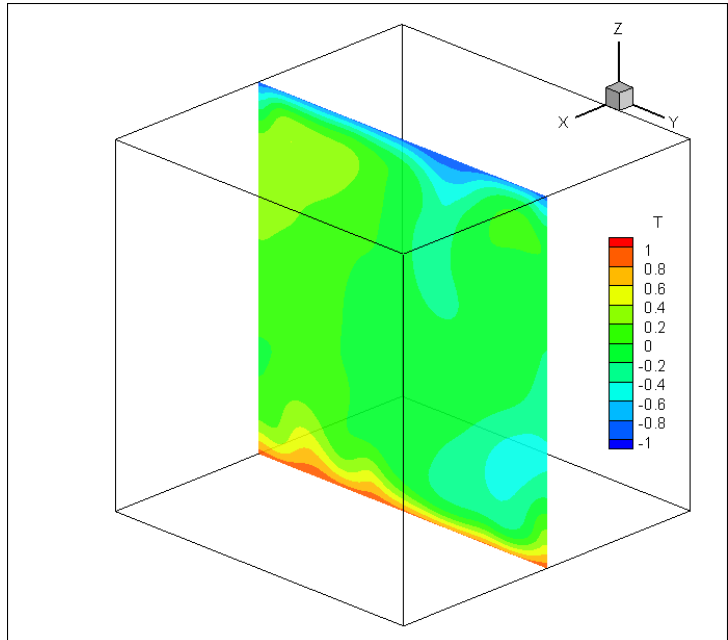

a)

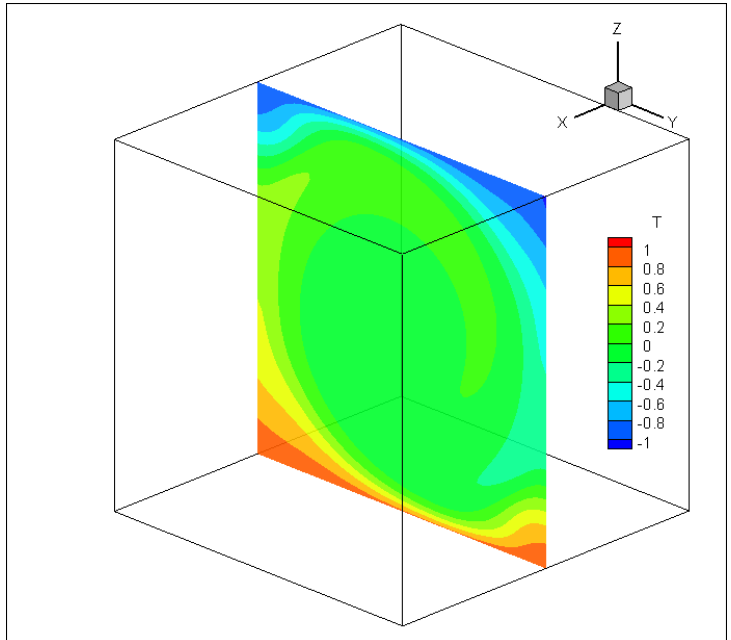

b)

Figure $5-$ Temperature contour of the turbulent flow for different interaction coefficients a) $N_{0}=0$ and $N_{0}=1$ at $x_{1}=0.5$.

isothermal conditions, we consider an incompressible electrically conductive medium with different electron concentration at the three dimensional area. To construct a mathematical model of the influence of external disturbances on the generation and evolution of large-scale inhomogeneities in the E-layer of the ionosphere, the motion of the electron concentration under the influence of a magnetic field, regardless of its strength directed horizontally along the axis, heat transfer were also considered.

The magnetohydrodynamic equation system is used for modeling of ionosphere processes. The numerical algorithm for the solution of three-dimensional mathematical model of the influence of the electron concentration on the dynamics of the ionosphere E-layer under non- 


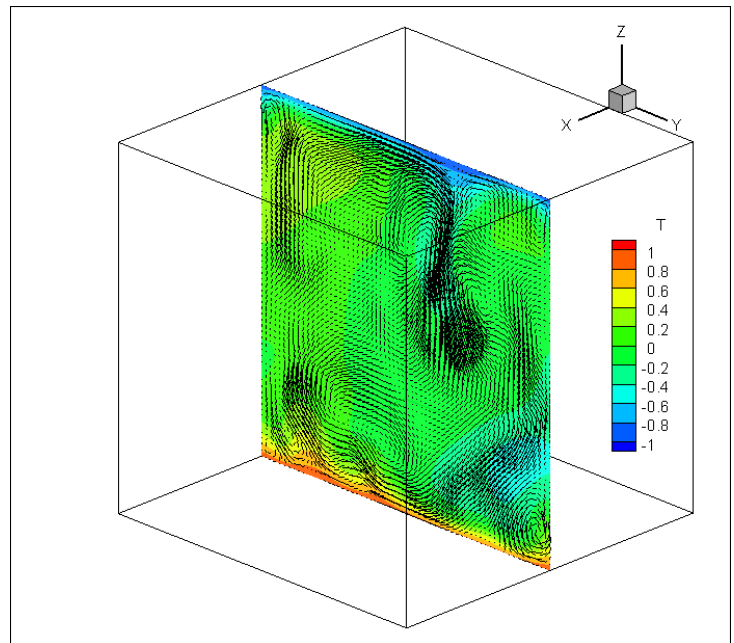

a)

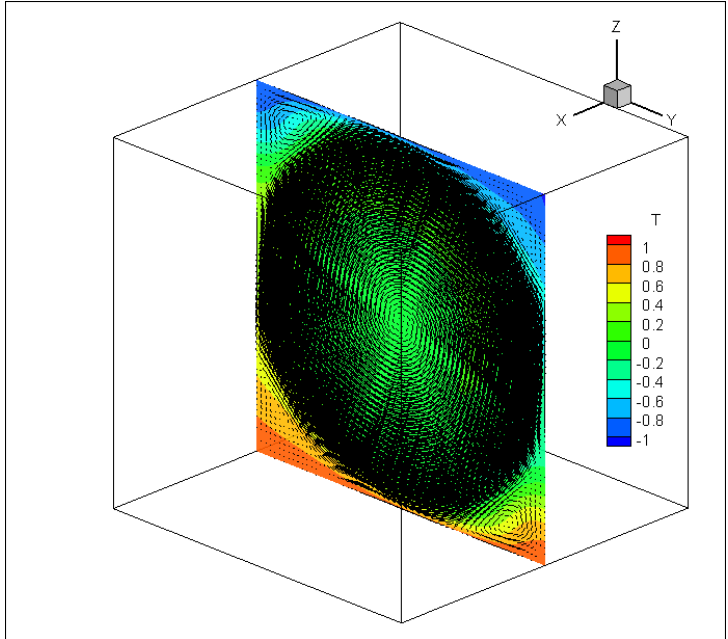

b)

Figure $6-$ Isotherms for different interaction coefficients a) $N_{0}=0$ and $N_{0}=1$ at $x_{1}=0.5$.

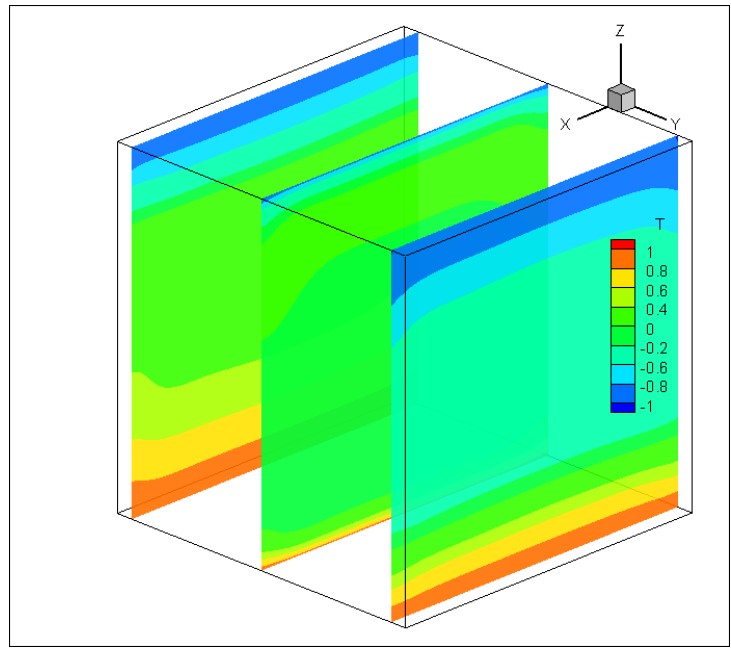

a)

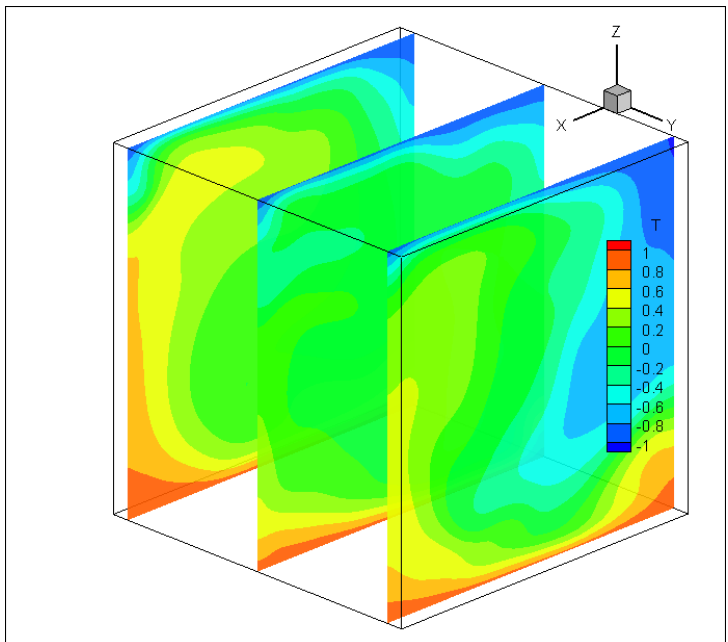

b)

Figure $7-$ Temperature contour of the turbulent flow for different interaction coefficients a) $N_{0}=0$ and $N_{0}=1$ at different sections $x_{2}=0.05 ; x_{2}=0.5 ; x_{2}=0.95$

isothermal condition is developed. For approximation of the convective and diffusion terms of the intermediate velocity field a finite-difference method in combination with penta-diagonal matrix is used, which allowed to reach fourth-order accuracy in space and third-order accuracy in time. For the solution of pressure the Poisson equation is solved, which ensures that the continuity equation is satisfied. The Poisson equation is transformed from the physical space into the spectral space by using a Fourier transform. The equation for temperature and electron concentration are solved by using Adams-Bashforth scheme. The concentration of electrons under the influence of a horizontal magnetic field shows, that the three-dimensional instability of convection flow with the increasing Stuart number, the development of heat 


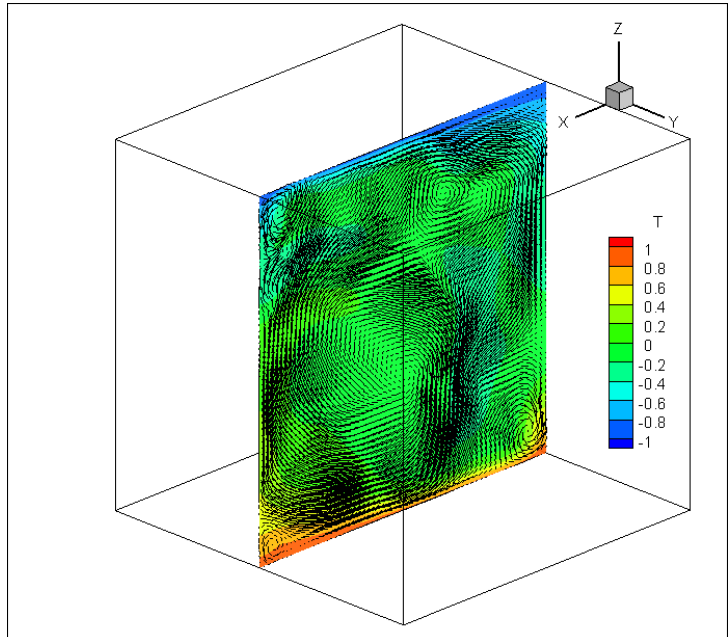

a)

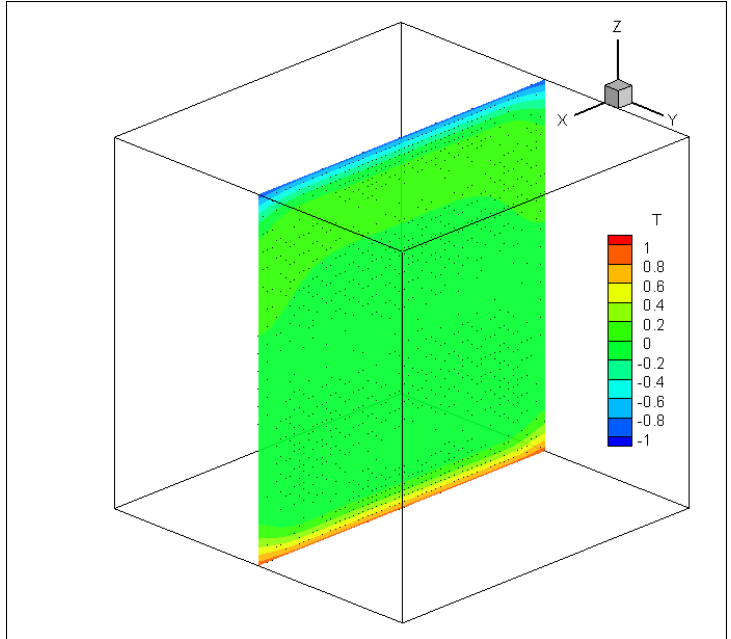

b)

Figure $8-$ Isotherms fordifferent interaction coefficients a) $N_{0}=0$ and $N_{0}=1$ at $x_{2}=0.5$ section.

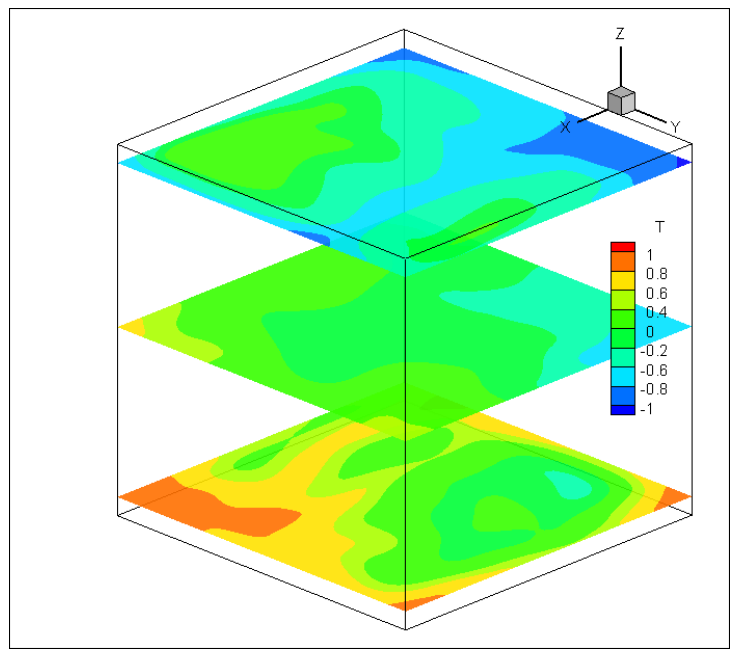

a)

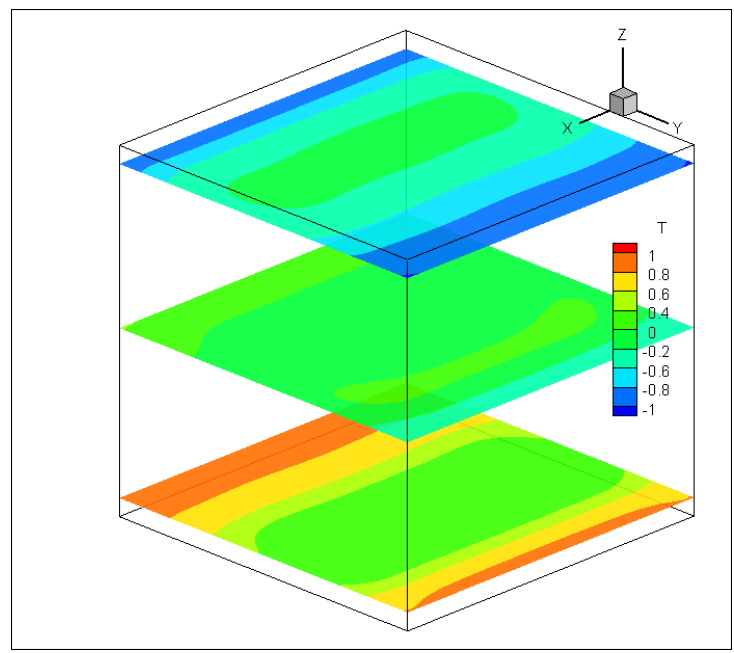

b)

Figure $9-$ Temperature contour of the turbulent flow for different interaction coefficients a) $N_{0}=0$ and $N_{0}=1$ at different sections $x_{3}=0.05 ; x_{3}=0.5 ; x_{3}=0.95$

transfer flow is more stable and static than where, the Stuart number is neglected. Heat transfer is largely suppressed by an external magnetic field. Convection flow will completely disappear under the action of the inhibitory force of the magnetic field.

Before investigating the influence of the magnetic field on the flow, the adequacy of the numerical algorithm was checked without applying a magnetic field. For this purpose, the Taylor Green test problem was carried out for various Reynolds numbers, where it has a good agreement with the Benchmark spectral method and analytical solutions. 


\section{Acknowledgment}

The work was supported by grant financing of scientific and technical programs and projects by the Ministry of Education and Science of the Republic of Kazakhstan Grant No. AP05133516 Development of a three-dimensional mathematical model of the effect of electron concentration on the dynamics of changes in the inhomogeneities of the ionosphere E-layer in the dependence of solar radiation intensityв Ђќ from the RI MM of RSE with the right of economic management Kazakh National University named after Al-Farabi.

\section{References}

[1] Ossakow S.L. "Ionospheric Irregularities," Rev. Geophys. Space Phys. 17,(1979):521.

[2] Fejer B.G. and Kelley M.C. "Ionospheric Irregularities," Rev. Geophys. Space Phys. 18,(1980): 401-454.

[3] Huba J. D., Hassam A. B., Schwartz, I. B., Keskinen, M. J. "Ionospheric turbulence - Interchange instabilities and chaotic fluid behavior," Geophysical Research Letters 12,(1985): 65-68.

[4] Saltzman B. "Finite Amplitude Free Convection as an Initial Value Problem-I," J. Atmos. Sci 19,(1962): 329.

[5] Lorenz E.N."Deterministic nonperiodic flow" J. Atmos. Sci. 20,(1963): 130-141.

[6] Hassam A. B., Hall, W., Huba, J. D., and Keskinen, M. J. "Spectral characteristics of interchange turbulence," J. Geophys. Res.,91(13), (1986):513-522.

[7] Benard H., "Les tourbillons cellulaires dans une nappe liquide" Rev. Gen. Sci. pures et appl. 11(1900): 1261-1271, 1309-1328.

[8] Rayleigh L., "On the convective currents in a horizontal layer of fluid when the higher temperature is on the under side," Phil. Mag. 32(1916): 529-546.

[9] Burattini P., Zikanov O. and Knaepen B., "Decay of magnetohydrodynamic turbulence at low magnetic Reynolds number" Fluid Mechanics 657(2010): 502-38.

[10] Knaepen B., Kassinos S. and Carati D., "Magnetohydrodynamic turbulence at moderate magnetic Reynolds number" Fluid Mechacincs 513(3)(2004): 199-220.

[11] Moreau, R., "Magnetohydrodynamics" Kluwer Academic (Dordrecht: 1990).

[12] Davidson, P. A., "An Introduction to Magnetohydrodynamics" Cambridge University Press (Cambridge: 2001)

[13] Vorobev, A., Zikanov, O., Davidson, P., Knaepen, B., "Anisotropy of magnetohydrodynamic turbulence at low magnetic Reynolds number," J.Physics of fluids, 7(2005): 125105.

[14] Saijadi, H., Amri Delouei, A., Sheikholeslami, M., Atashafrooz., M., Succi, S., J.Physica A 515 (2019):474-496.

[15] Abdibekova, A., Zhakebayev, D., Abdigaliyeva, A.,Zhubat, K. "Modeling of turbulence energy decay based on hybrid methods," J. Engineering Computations 35(5)(2018): 1965-1977.

[16] Zhakebayev D., Zhumagulov B. and Abdibekova A., "The decay of MHD turbulence depending on the conductive properties of the environment," Magnetohydrosynamics 50(2)(2014): 121-38.

[17] Taylor G.I. and Green A.E., "Mechanism of production of small eddies from large ones, " Proceedings of the royal society, Mathematics and physical sciences 158(895)(1937): 499-521. 